\title{
Carnets
}

Revue électronique d'études françaises de l'APEF

Première Série - 3| 2011

$L^{\prime}($ In)vraisemblable

\section{Les dieux sont moqueurs}

\section{François Matton}

\section{OpenEdition}

Journals

Édition électronique

URL : http://journals.openedition.org/carnets/6252

DOI : $10.4000 /$ carnets.6252

ISSN : 1646-7698

\section{Éditeur}

APEF

Édition imprimée

Date de publication : 2 janvier 2011

Pagination : 229-231

\section{Référence électronique}

François Matton, "Les dieux sont moqueurs », Carnets [En ligne], Première Série - 3 | 2011, mis en ligne le 18 juin 2018, consulté le 24 septembre 2020. URL : http://journals.openedition.org/carnets/ 6252 ; DOI : https://doi.org/10.4000/carnets. 6252

\section{(a) (1) @}

Carnets est mis à disposition selon les termes de la licence Creative Commons - Atribution - Pas d'utilisation commerciale 4.0 International. 


\section{LES DIEUX SONT MOQUEURS}

FRANÇOIS MATTON 


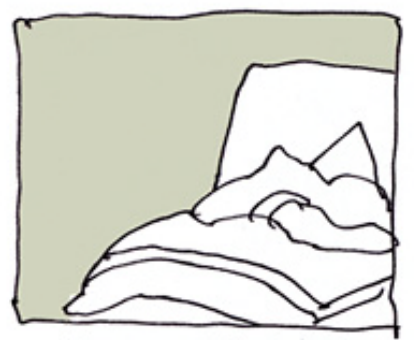

i'mumanité vieillit

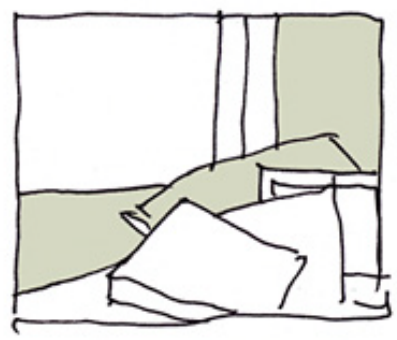

In tentation earite

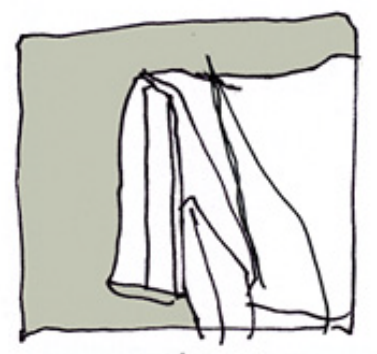

la natalité décroit

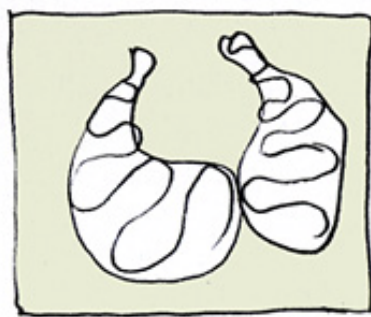

la france reste prolitique


Б๑四G0

DDOADEE

In question se pose

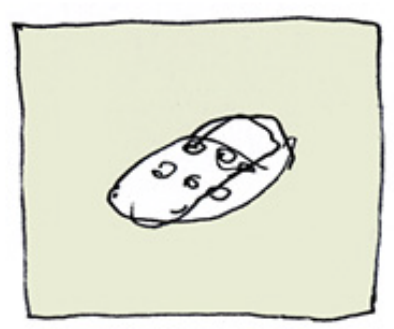

I'Amérique avance 


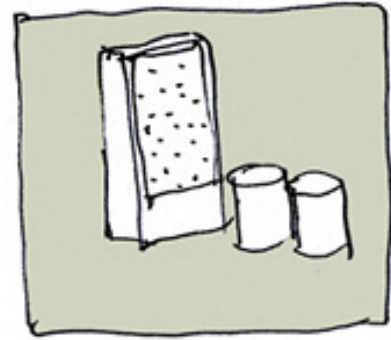

Paris capitule

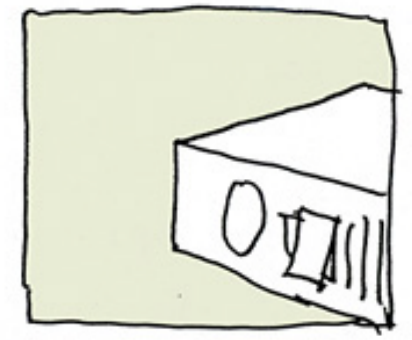

I'habitude de hrieste reperd

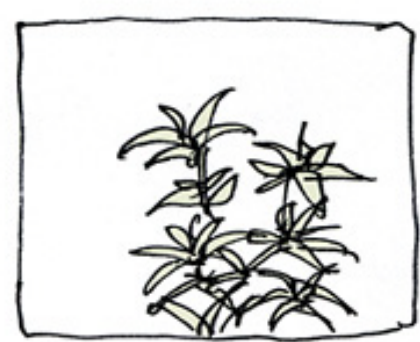

le tablean differe

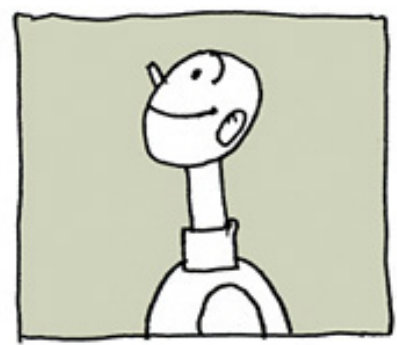

In sociologie explique

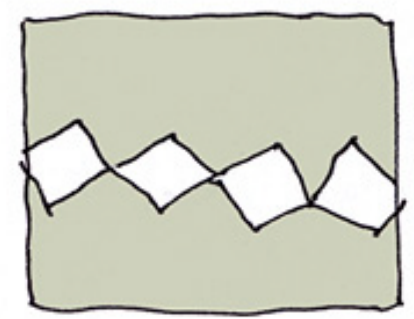

le noir revient en force

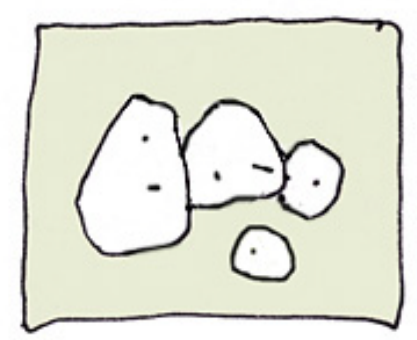

le paysage est suspendu

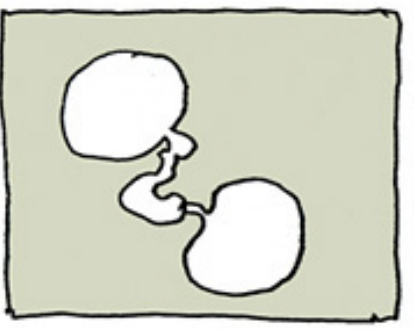

les élus tirent la sounctte

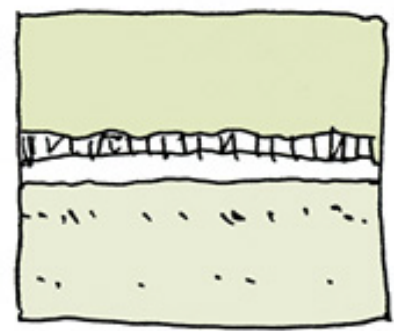

les dienx sont moqueurs

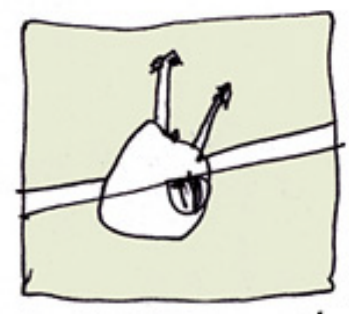

le díbat est onvert

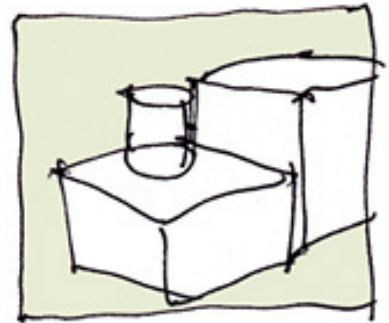

l'économie flambe

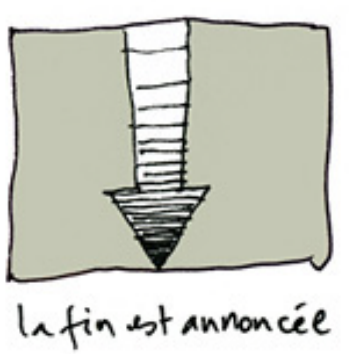

